\title{
A Proteomic Approach to Identify Seminal Plasma Proteins in Ostrich (Struthio camelus)
}

\author{
C. Pandian ${ }^{1 *}$, S.T. Selvan ${ }^{2}$, M. Parthiban ${ }^{3}$ and S.M.K. Karthickeyan ${ }^{4}$ \\ ${ }^{1}$ Department of Poultry Science, MVC, TANUVAS, Chennai-07, Tamil Nadu, India \\ ${ }^{2}$ PGRIAS, TANUVAS, Kattupakkam 603 203, Tamil Nadu, India \\ ${ }^{3}$ Department of Animal Biotechnology, MVC, TANUVAS, Chennai-07, Tamil Nadu, India \\ ${ }^{4}$ Dept. of Animal Genetics and Breeding, MVC, TANUVAS, Chennai-07, Tamil Nadu, India \\ *Corresponding author
}

\begin{tabular}{|c|c|}
\hline \multicolumn{2}{|r|}{ A B S T R A C T } \\
\hline & $\begin{array}{l}\text { The protein bands in ostrich seminal plasma (OSP) were identified by using Sodium } \\
\text { Dodecyl Sulphate Polyacrylamide Gel Electrophoresis (SDS-PAGE) and Matrix Assisted }\end{array}$ \\
\hline $\begin{array}{l}\text { Ke y w o r d s } \\
\text { Proterin bands, } \\
\text { ostrich seminal } \\
\text { plasma (OSP) }\end{array}$ & $\begin{array}{l}\text { Laser Desorption Ionization Mass Spectrometry (MALDI MS) proteomic analysis and } \\
\text { compared with NCBI reference sequence. The results revealed that OSP had five major } \\
\text { specific proteins bands namely, OSP-I (GATA Zinc finger domain containing protein 1), } \\
\text { OSP-II (GATA Zinc finger domain containing protein 1), OSP- III (E3 ubiquitin protein } \\
\text { ligase RNF 216, OSP-IV (Mitotic spindle assembly checkpoint protein MAD1) and OSP- }\end{array}$ \\
\hline Article Info & V (Dual specificity phosphatase DUPD1). The estimated molecular weight of OSP-I \\
\hline $\begin{array}{l}\text { Accepted: } \\
\text { 28 August } 2017 \\
\text { Available Online: } \\
\text { 10 September } 2017\end{array}$ & $\begin{array}{l}\mathrm{kDa}) \text {, OSP-IV }\left(M_{r} 30.71 \text { to } 40.90 \mathrm{kDa}\right) \text { and OSP-V }\left(M_{r} 21.66 \text { to } 26.26 \mathrm{kDa}\right) \text {. The results of } \\
\text { our study provide basic knowledge of the protein composition of ostrich seminal plasma } \\
\text { highlighting important physiological pathways which may play crucial roles in the sperm } \\
\text { environment after ejaculation. This knowledge can be the basis to further develop } \\
\text { procedures improving the reproduction of farmed ostrich. }\end{array}$ \\
\hline
\end{tabular}

\section{Introduction}

Ratite species such as ostrich (Struthio camelus), emu (Dromaius novaehollandiae) and rhea (Rhea americana) are fundamentally attractive for farming to produce leather, meat, oil and feathers. Unpredictable egg production, unstable fertility, poor hatchability and poor chick survival are some of the major constraints in viable ostrich farming. To achieve rapid and sustained genetic improvement, ostrich farming needs to adopt advanced reproductive technological tools. In this composition of seminal plasma has a great influence on the biological quality of the ostrich semen. Seminal plasma (SP) is known to play an important role in fertilization. However, the variability found in its composition among species, males and even fractions of the same ejaculate has made difficult to completely understand its effect in sperm function. Proteins are one of the major seminal plasma components that modulate sperm functionality. Alterations at the molecular level in spermatozoa and seminal plasma can affect male fertility. There are also reports that seminal plasma proteins affect sperm motility (Yoshida et al., 2008). 
These proteins could either display negative (La Falci et al., 2002) or positive effects on sperm motility (Qu et al., 2007). Hence this study was carried out to determine seminal plasma protein expression of ostrich semen that can serve as potential biomarkers for male infertility.

\section{Materials and Methods}

This experiment was carried out at Post Graduate Research Institute in Animal Sciences, Tamil Nadu Veterinary and Animal Sciences University, Kattupakkam, Kanchipuram, Tamil Nadu during 2014 2016. This experiment was designed to analyse the protein profile of seminal plasma in nine ostrich. Selected nine male ostrich were trained for semen collection by teaser method as recommended by earlier authors (Rybnik et al., 2007).

Seminal plasma was separated from the semen by centrifugation (2500 rpm for $15 \mathrm{~min}$ at $20^{\circ} \mathrm{C}$ ) and stored at $80^{\circ} \mathrm{C}$ until assayed. A total of 126 seminal plasma sample (each 14 sample from nine male ostrich) were used for this study. The major proteins in seminal plasma were identified by sodium dodecyl sulphate polyacrylamide gel electrophoresis (SDS PAGE) and the prominent protein bands were analysed by matrix assisted laser desorption ionization mass spectrometry (MALDI MS) to identify the protein. The MALDI MS results were compared with the available sequences in GenBank to find out the proteins.

\section{Results and Discussion}

\section{Identification of seminal plasma protein in ostrich}

Protein sequence results matches for each of the protein bands in ostrich seminal plasma are presented in table 1 and Plate 1.
Ostrich seminal plasma protein band I (OSP-I)

GATA Zinc finger domain containing protein 1 (Struthio camelus australis)

GATA zinc fingers are zinccontaining domains found in a number of transcription factors (erythroid specific transcription factor and nitrogen regulatory proteins). Some members of this class of zinc fingers specifically bind the DNA sequence $(\mathrm{A} / \mathrm{T})$ GATA $(\mathrm{A} / \mathrm{G})$ in the regulatory regions of genes giving rise to the name of the domain.

Ostrich seminal plasma protein band II (OSP-II)

\section{GATA Zinc finger domain containing protein 1 (Struthio camelus australis)}

The OSP-II protein band also matched with the GATA Zinc finger domain containing protein 1 (Struthio camelus australis).

Therefore, the following three assumptions were derived based on the results.

The OSP-II might be a subunit or isoform variant of protein band I (OSP-I).

OSP-II might be a degraded or cleaved product of OSP-I. OSP-I and OSP-II might be part of the so-called family protein.

Ostrich seminal plasma protein band III (OSP-III)

\section{E3 ubiquitin protein ligase RNF 216 (Struthio camelus australis)}

This was the $3^{\text {rd }}$ major seminal plasma protein identified in the present study and the protein was reported to be involved in the capacitatition of spermatozoa which was located in acrosomal membrane. 
Table.1 Major Protein bands identified in ostrich seminal plasma

\begin{tabular}{|c|c|c|c|c|c|}
\hline Characteristics & $\begin{array}{c}\text { GATA Zinc } \\
\text { finger domain } \\
\text { containing } \\
\text { protein } 1 \text { (Struthio } \\
\text { camelus australis) }\end{array}$ & $\begin{array}{c}\text { GATA Zinc } \\
\text { finger domain } \\
\text { containing } \\
\text { protein } 1 \text { (Struthio } \\
\text { camelus australis) }\end{array}$ & $\begin{array}{c}\text { E3 ubiquitin } \\
\text { protein ligase } \\
\text { RNF } 216 \text { (Struthio } \\
\text { camelus australis) }\end{array}$ & $\begin{array}{c}\text { Mitotic spindle } \\
\text { assembly checkpoint } \\
\text { protein MAD1 } \\
\text { (Struthio camelus } \\
\text { australis) }\end{array}$ & $\begin{array}{l}\text { Dual specificity } \\
\text { phosphatase } \\
\text { DUPD1 (Struthio } \\
\text { camelus australis) }\end{array}$ \\
\hline Protein band & OSP-I & OSP-II & OSP-III & OSP-IV & OSP-V \\
\hline $\begin{array}{l}\text { NCBI reference } \\
\text { sequence }\end{array}$ & XP_009672619.1 & XP_009672619.1 & XP_00968359.1 & XP_009688373.1 & XP_009669492.1 \\
\hline Locus & XP_009672619 & XP_009672619 & XP_00968359 & XP_009688373 & XP_009669492 \\
\hline Amino acids & 151 aa & 151 aa & 925 aa & 717 aa & 214 aa \\
\hline Version & GI 697481422 & GI 697481422 & GI 697513075 & GI 697438336 & GI 697472637 \\
\hline Source/ organism & $\begin{array}{c}\text { Struthio camelus } \\
\text { australis }\end{array}$ & $\begin{array}{c}\text { Struthio camelus } \\
\text { australis }\end{array}$ & $\begin{array}{c}\text { Struthio camelus } \\
\text { australis }\end{array}$ & $\begin{array}{c}\text { Struthio camelus } \\
\text { australis }\end{array}$ & $\begin{array}{c}\text { Struthio camelus } \\
\text { australis }\end{array}$ \\
\hline Isolate & BGI_N308 & BGI_N308 & BGI_N308 & BGI_N308 & BGI_N308 \\
\hline Sub species & australis & australis & australis & australis & australis \\
\hline $\begin{array}{l}\text { Gene prediction } \\
\text { method }\end{array}$ & $\begin{array}{c}\text { Gnomon, } \\
\text { supported by } \\
\text { mRNAand EST } \\
\text { evidence }\end{array}$ & $\begin{array}{c}\text { Gnomon, } \\
\text { supported by } \\
\text { mRNAand EST } \\
\text { evidence }\end{array}$ & $\begin{array}{l}\text { Gnomon, } \\
\text { supported by EST } \\
\text { evidence }\end{array}$ & Gnomon & Gnomon \\
\hline $\begin{array}{l}\text { Genomic sequence } \\
\text { number }\end{array}$ & NW009271130.1 & NW009271130.1 & NW009272015.1 & NW009270416.1 & NW009270910.1 \\
\hline Documentation & $\begin{array}{l}\text { NCBI'S } \\
\text { Annotation } \\
\text { process }\end{array}$ & $\begin{array}{l}\text { NCBI'S } \\
\text { Annotation } \\
\text { process }\end{array}$ & $\begin{array}{l}\text { NCBI'S } \\
\text { Annotation } \\
\text { process }\end{array}$ & $\begin{array}{l}\text { NCBI'S Annotation } \\
\text { process }\end{array}$ & $\begin{array}{c}\text { NCBI'S Annotation } \\
\text { process }\end{array}$ \\
\hline Annotation status & Full annotation & Full annotation & Full annotation & Full annotation & Full annotation \\
\hline $\begin{array}{l}\text { Annotation } \\
\text { pipeline }\end{array}$ & $\begin{array}{l}\text { NCBI eukaryotic } \\
\text { genome annotation }\end{array}$ & $\begin{array}{l}\text { NCBI eukaryotic } \\
\text { genome annotation }\end{array}$ & $\begin{array}{l}\text { NCBI eukaryotic } \\
\text { genome annotation }\end{array}$ & $\begin{array}{l}\text { NCBI eukaryotic } \\
\text { genome annotation }\end{array}$ & $\begin{array}{l}\text { NCBI eukaryotic } \\
\text { genome annotation }\end{array}$ \\
\hline Completeness & $\begin{array}{l}\text { Incomplete on the } \\
\text { amino end }\end{array}$ & $\begin{array}{l}\text { Incomplete on the } \\
\text { amino end }\end{array}$ & Full length & Full length & Full length \\
\hline Gene & GATAD1 & GATAD1 & RNF216 & MAD1L1 & DUPD1 \\
\hline
\end{tabular}


Plate.1 SDS PAGE displaying the protein profile of seminal plasma in ostrich (a) \& (b) Resolved protein bands (c) Molecular weight of different protein bands assessed through molecular weight marker
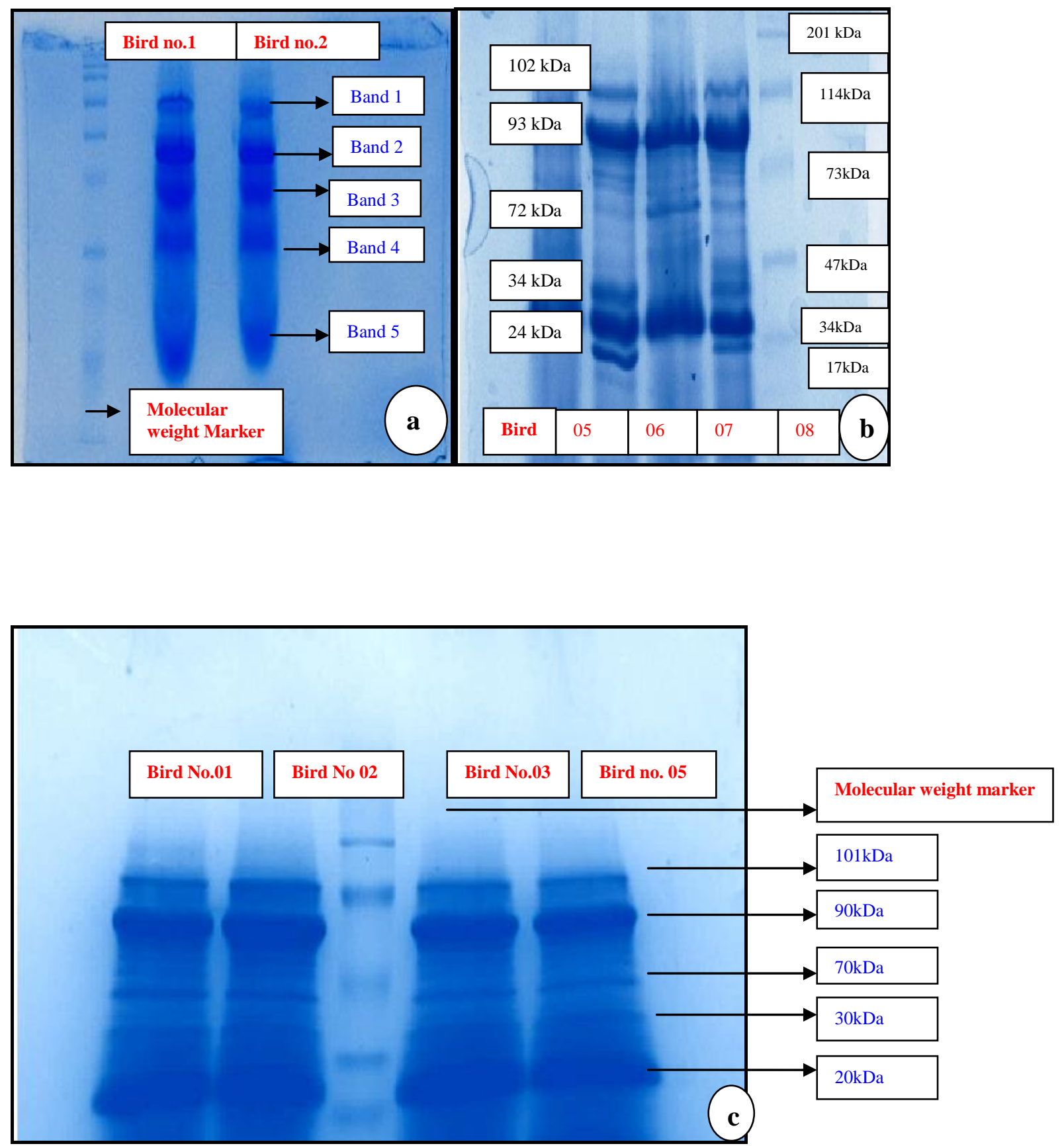
A large number of RING finger (RNF) proteins were present in eukaryotic cells and the majority of them are believed to act as E3 ubiquitin ligases. Pertinent to the search for new semen quality/fertility markers, ubiquitin is one of the secretory proteins in the epididymis and plays an important role in gametogenesis and fertilization.

\section{Ostrich seminal plasma protein band IV (OSP-IV)}

Mitotic spindle assembly checkpoint protein MAD1 (Struthio camelus australis)

This is the $4^{\text {th }}$ major seminal plasma protein identified in the present study. This protein was mainly found in the secretion of epdidymis, seminal vesicle and testis.

\section{Ostrich seminal plasma protein band V (OSP-V)}

\section{Dual specificity phosphatase DUPD1 (Struthio camelus australis)}

This is the $5^{\text {th }}$ major protein identified in the proteomic study of ostrich seminal plasma. Similar findings were observed by Thurston (1976) who identified six major protein fractions in turkey seminal plasma and observed that beta-3 fraction was the most prominent in turkey seminal plasma protein. Similarly, Thurston et al., (1982) observed nine bands in guinea fowl seminal plasma and Marzoni et al., (2013) detected a total of 83 protein spots in seminal plasma of chicken.

\section{Molecular weight of different protein bands of ostrich seminal plasma}

The molecular weight $(\mathrm{kDa})$ of five major ostrich seminal plasma protein bands namely, OSP-I to OSP-V were estimated by using standard protein marker (Bio-Rad). The molecular weight of five ostrich seminal plasma protein bands (OSP I, II, III, IV and V) showed no significant difference among individual ostrich. All the 5 major expressed protein bands had a molecular weight ranging from $21.66 \mathrm{kDa}$ to $102.34 \mathrm{kDa}$. The estimated molecular weight of ostrich seminal plasma protein viz., OSP I (range between $94.51 \mathrm{kDa}$ and $102.34 \mathrm{kDa}$ ), OSP II (75.19 kDa and 93.07 kDa), OSP III (59.58 $\mathrm{kDa}$ and $72.76 \mathrm{kDa})$, OSP IV $(30.71 \mathrm{kDa}$ and $40.90 \mathrm{kDa})$ and OSP V (21.66 kDa and $26.26 \mathrm{kDa})$ showed wide variations in expression. Thurston et al., (1993) opined that the molecular weight of turkey seminal plasma proteins ranged from 25 to $80 \mathrm{kDa}$.

OSP-I and OSP-II identified in the present study are considered family of protein or isoform or identical subunits. Although the two proteins have different range of molecular weight, they are composed of same protein and thus may be isoenzymes, which is in agreement with the reports of Thurston et al., (1993), who had found that, similar isoform for turkey seminal plasma enzyme. However, comprehensive proteomic study on ratites seminal plasma or even other poultry species has not been studied adequately for comparison. Ubiquitin (OSP-III) protein identified in this study is involved in the ubiquitin-proteosome pathway in gametogenesis and fertilization. Ubiquitination has been implicated in targeted proteolysis of histones and other proteins during spermatid elongation, in the degradation of the sperm mitochondria after fertilization, and in the sperm-zona penetration during fertilization as reported by Sutovsky et al., (2004).

Mitotic spindle assembly checkpoint protein (MAD1) and Dual specificity phosphatase (DUPD1) protein were also identified in ostrich seminal plasma and many authors believe that this type of protein function to stabilize the spermatozoa against premature capacitation and spontaneous acrosome reaction.(Mortarino et al., 1998; Moura et al., 2006; Drabovich et al., 2011; Milardi et al., 2012).

This present study revealed, that proteomic analysis using SDS-PAGE reference map could represent a useful tool for the identification of still poorly understood nature and function of the ostrich seminal plasma proteins. Further, 
correlation of seminal plasma protein with fertility parameters is the need of hour to identify potential marker for evaluation of fertility in male ostrich.

\section{Acknowledgement}

The authors acknowledge the Tamil Nadu Veterinary and Animal Sciences University, Chennai-51 for providing all facilities to do the doctoral research work.

\section{References}

Drabovich, A.P., K. Jarvi and E.P. Diamandis, 2011. Verification of male infertility biomarkers in seminal plasma by multiplex selected reaction monitoring assay. Mol. Cell. Proteomics. 10: M110.004127.

La Falci, $\quad$ V.S.N., H. Tortorella, J. L. Rodrigues, A. Brandelli 2002. Seasonal variation of goat seminal plasma proteins. Theriogenology, 57: 1035-1048.

Marzoni, M., A, Castillo, S. Sagona, L. Citti, S. Rocchiccioli, I. Romboli and A. Felicioli, 2013. A proteomic approach to identify seminal plasma proteins in roosters (Gallus gallus domesticus). Anim. Reprod. Sci. 140 (3-4): 216-23.

Milardi, D., G. Grande, F. Vincenzoni, I. Messana, A. Pontecorvi, L. De Marinis, M. Castagnola and R. Marana, 2012. Proteomic approach in the identification of fertility pattern in seminal plasma of fertile men. Fertil. Steril. 97: 67-73.

Mortarino, M., G.Tedeschi, A.Negri, F. Ceciliani, L.Gottardi, G. Maffeo and S. Ronchi, 1998. Two-dimensional polyacrylamide gel electrophoresis map of bull seminal plasma proteins. Electrophoresis, 70: 797-801.
Moura, A.A., D.A. Chapman and G.J Killian, 2006. Identification of proteins in the accessory sex gland fluid associated with fertility indexes of dairy bulls: a proteomiv approach. J. Androl. 27(2): 201-211.

Qu, F., X. Ying, W. Guo, Q. Guo, G. Chen, Y. Liu, Z. Ding 2007. The role of Zn-alpha2 glycoprotein in sperm motility is mediated by changes in cyclic AMP. Reproduction, 134: 569-576.

Rybnik, P.K., J.O. Horbanczuk, H. Naranowicz, E. Lukaszewicz and I.A. Malecki, 2007.Semen collection in the ostriches using a dummy or a teaser female. Brit. Poultry Sci. 48: 635-643.

Sutovsky, P., T. Geary, K. M. Baska, G. Manandhar, D. Feng, K.W. Lovercamp, and M. Sutovsky, 2004. Ubiquitin as an objective marker of semen quality and fertility in bulls. Proceedings, Applied Reproductive Strategies in Beef Cattle September 1 and 2, 2004, North Platte, Nebraska. Pp.185-199.

Thurston, R. J., 1976. Physiopathological studies of semen production in the domestic turkey. Ph.D. Dissertation, Univ. Missouri, Columbia, MO.

Thurston, R.J., N. Korn, D.P. Froman and A.B. Bodine, 1993. Proteolytic enzymes in seminal plasma of domestic turkey (Meleagris gallopavo). Biol. Reprod. 48: 393-402.

Thurston, R.J., R.A. Hess, B.L. Hughes and D.P. Froman, 1982. Ultrastructure of the guinea fowl (Numidia meleagris) spermatozoa. Poultry Sci. 61:1738-1743.

Yoshida, M., N. Kawano, K. Yoshida. 2008. Control of sperm motility and fertility: diverse factors and common mechanisms. Cell. Mol. Life Sci. 65: 3446-345.

\section{How to cite this article:}

Pandian, C., Selvan, S.T., Parthiban, M. and Karthickeyan, S.M.K. 2017. A Proteomic Approach to Identify Seminal Plasma Proteins in Ostrich (Struthio camelus). Int.J.Curr.Microbiol.App.Sci. 6(9): 3073-3078. doi: https://doi.org/10.20546/ijcmas.2017.609.378 